Bawden, F. C. \& Kassanis, B. (1954). J. gen. Microbiol. 10, 160-173.

\title{
Some Effects of Thiouracil on Virus-infected Plants
}

\author{
By F. C. BAWDEN AND B. KASSANIS \\ Rothamsted Experimental Station, Harpenden, Hertfordshire
}

SUMMARY: Submerging leaves in water soon after they are inoculated with viruses can prevent infection, and for studying factors that affect the rate of virus multiplication leaves should not be placed in solutions until a day after inoculation.

The rate at which viruses multiply in tobacco leaves is decreased by spraying with solutions of thiouracil, but less so than by floating leaves in the solutions. The physiological state of floated leaves affects the extent to which thiouracil impedes virus multiplication; least virus is produced in the presence of thiouracil when the condition of leaves otherwise most favours virus formation. Multiplication of virus can be checked at any time by thiouracil, but is most affected when leaves contain little virus; multiplication is resumed when thiouracil is removed. Thiouracil impedes the multiplication in tobacco of all viruses tested, but not of a tobacco necrosis virus in French bean or broad bean mottle virus in Vicia faba.

When mixed with inocula, thiouracil can prevent infection from occurring, both in tobacco and French bean. It also affects the growth and appearance of both plants. These effects, unlike the impedance of virus multiplication in tobacco, are not counteracted by an excess of uracil. Tobacco leaves in which tobacco mosaic virus is multiplying develop necrotic spots and rings when treated with thiouracil, and local lesions can be made evident by spraying inoculated leaves. Necrotic lesions also occur on $V$. faba infected with broad-bean mottle virus and treated with thiouracil.

Commoner \& Mercer $(1951,1952)$ found that thiouracil inhibits the production of tobacco mosaic virus in tobacco leaves and that its inhibitory action is counteracted by an excess of uracil. In their experiments, detached tobacco leaves were rubbed over their whole upper surfaces with the virus, and kept for $24 \mathrm{hr}$. at $24^{\circ}$ under a bell jar in continuous light of 120 f.c. Disks $12 \mathrm{~mm}$. in diameter were then cut from the leaf blades and floated in a nutrient solution with various concentrations of thiouracil and uracil. The disks were kept at $24^{\circ}$ and in continuous light of 120 f.c. until they were macerated for assays of their virus contents. We have not used these exact conditions, but we have repeatedly confirmed the observation that thiouracil can inhibit the production of tobacco mosaic virus and that uracil neutralizes this effect of thiouracil. By working under different and varying conditions, we have found that the extent to which thiouracil inhibits virus production varies with the physiological condition of the leaves. Perhaps unexpectedly, inhibition is more complete the more actively the leaf would otherwise have produced virus; not only is virus production decreased proportionally more in such conditions by thiouracil, but less total virus is formed than in leaves that are physiologically less capable of producing virus. Experiments with various viruses and hosts have further shown that thiouracil can affect the behaviour of healthy and infected plants in many ways that are not apparent when tobacco leaves recently inoculated with tobacco mosaic virus are floated in nutrient solutions. 


\section{MATERIALS AND METHODS}

The viruses and host plants used were: tobacco mosaic virus (TMV), tomato aucuba mosaic virus, the Rothamsted culture of tobacco necrosis virus (RTNV), potato virus $Y$, and henbane mosaic virus in tobacco (Nicotiana tabacum L. var. White Burley); TMV and tomato bushy stunt virus in N. glutinosa L; RTNV in French bean (Phaseolus vulgaris L. var. Prince), and broad bean mottle virus in broad bean (Vicia faba L.).

Inocula were either purified virus preparations or sap freshly expressed from infected leaves. Inoculations were made by rubbing the whole upper surfaces of leaves as uniformly as possible with the forefinger wet with inoculum. When effects on virus production were studied, the inocula were either undiluted sap or purified TMV at $1 \mathrm{~g} . / \mathrm{l}$; ; when experiments involved counts of local lesions, the inocula were suitably diluted to give conveniently spaced lesions.

Thiouracil was mostly used as a solution of the potassium salt in water; comparable results were obtained with solutions of thiouracil made by warming suspensions in water. The effect of thiouracil on virus multiplication was mainly studied by floating whole leaves in solutions contained in shallow enamel dishes covered with glass sheets. Unless otherwise stated, the dishes were kept in the fluctuating conditions of a warmed glasshouse with a mean temperature of $20^{\circ}$ and without artificial light. The solutions all contained 0.3 g. sulphonilamide/l., which does not affect virus multiplication but keeps the leaves and fluids free from bacterial growth; they usually also contained $10 \mathrm{~g}$./l. sucrose and $0.2 \mathrm{~g} / / \mathrm{l} . \mathrm{Ca}\left(\mathrm{H}_{2} \mathrm{PO}_{4}\right)_{2} \mathrm{H}_{2} \mathrm{O}$, because leaves floated in this nutrient solution produce more TMV than do leaves floated in water (Kassanis, 1953). Leaves from 4 to 6 in. long were inoculated on the plants, washed with running water, and the plants were kept in the glasshouse for $\mathbf{2 4} \mathbf{~ h r}$., when the inoculated leaves were detached and floated. Leaves were not floated immediately after inoculation because this alone decreases the number of local infections obtained, and because thiouracil not only affects the rate of virus formation but can also prevent infection from occurring. Evidence for these two statements is given later.

Many experiments were also made with leaves left on the plants and kept under ordinary glasshouse conditions. In these, solutions of thiouracil were either sprayed over the leaves with a glass atomizer, or the thiouracil was added to the inoculum and rubbed over the leaves together with the viruses.

The relative virus contents of leaf extracts were usually measured serologically. Except with potato virus $\boldsymbol{Y}$ and henbane mosaic virus, which denature when heated and were therefore titrated from the fluids obtained by centrifuging sap at 8000 r.p.m., the leaf extracts were all heated to $60^{\circ}$ before centrifuging. Heating not only coagulates the normal plant proteins and gives stable fluids for titration, but also aggregates the particles of anisometric viruses such as TMV and potato virus $X$ and makes the precipitation titre a more reliable measure of virus content (Bawden \& Pirie, 1945). The titrations were made by adding $1 \mathrm{ml}$. of the extracts at various dilutions to $1 \mathrm{ml}$. 
of antiserum at a constant dilution of 1/100. The precipitation end-point was taken as the highest dilution at which a visible precipitate was produced after $3 \mathrm{hr}$. at $50^{\circ}\left(40^{\circ}\right.$ with potato virus $Y$ and henbane mosaic virus). The amount of TMV in extracts was sometimes measured by isolating and weighing the virus from a known volume of extract. In some experiments with TMV and RTNV the relative virus contents of extracts were estimated by infectivity tests, using the local-lesion method.

\section{EXPERIMENTAL}

\section{Some effects of immersing inoculated leaves in water}

All the viruses and hosts with which we have experimented give fewer local infections when inoculated leaves are immersed in water than when they are kept in air. The results of a typical experiment with TMV and $N$. glutinosa are given in Table 1 . Two different treatments were used. Leaves were

Table 1. The effect of submerging Nicotiana glutinosa leaves on numbers of local lesions produced by tobacco mosaic virus

\section{Treatment}

A. Leaves cut into halves

(a) Halves left on the plants

(b) Halves submerged in water Ratio $b: a$

B. Whole detached leaves

(a) Halves in air

(b) Halves submerged in water Ratio $b: a$
Numbers of lesions per plant*

$\begin{array}{cccc}\text { Plant 1 } & \text { Plant 2 } & \text { Plant 3 } & \text { Plant 4 } \\ \text { 345 } & 671 & 270 & 246 \\ 96 & 222 & 88 & 70 \\ 0.28 & 0.33 & 0.33 & 0.28 \\ \text { Plant 5 } & \text { Plant 6 } & \text { Plant 7 } & \text { Plant 8 } \\ 216 & 524 & 493 & 359 \\ 91 & 233 & 302 & 169 \\ 0.42 & 0.44 & 0.61 & 0.47\end{array}$

* Eight leaves were inoculated on each plant, with TMV at $10 \mathrm{mg} . / 1$.

inoculated on the plants; for one treatment, they were cut length-wise along the mid-ribs, and one lot of half-leaves was left on the plant and the other submerged in water; for the other, the leaves were detached from the plants, and put vertically in tumblers with the mid-ribs at water-level, so that the lower halves were submerged while the upper halves were in air. Submersion in water decreases the numbers of lesions much more with the cut leaves than with the whole leaves. Whether this happens because the exposed halves of the whole leaves to some extent neutralize the action of submersion on the other halves, or because cut halves are more readily penetrated by water, is unknown.

The extent to which submersion decreases the numbers of infections varies with the physiological state of the leaves. With $N$. glutinosa plants bearing eight to ten inoculable leaves, the oldest leaves are the most affected; when inoculated and submerged they may give only a tenth as many lesions as they would give in air, whereas submerging the youngest leaves may not decrease the numbers of lesions by as much as one half. With all the viruses and hosts we have tested, the effect of submersion decreases with increasing time after inoculation and is not appreciable after a day. With RTNV in French bean 
submersion 3-4 hr. after inoculation is usually ineffective, but with TMV in $N$. glutinosa infections are still inhibited by submersion 6-8 hr. after inoculation. No doubt the time at which the effect ceases to operate will vary, not only with individual viruses and host plants, but also with the temperature and many other factors. A simple explanation of the phenomenon would be that, for a time after inoculation, virus particles are loosely bound and can be dissolved out of the wounded cells. That this is unlikely to be the whole explanation, however, is suggested by the fact that the time after inoculation during which submersion decreases numbers of lesions is considerably longer than the time taken for rubbed leaves to regain their resistance to infection when sprayed with virus solutions (Kalmus \& Kassanis, 1945). Also, submersing inoculated leaves in the virus solutions used as inocula decreases the numbers of lesions as much as does submersion in water, suggesting that virus particles cannot freely enter and leave the wounded cells.

From experiments comparing the numbers of local lesions produced by dry and wet inocula on wilted and sprayed leaves, Yarwood (1952) concluded that 'water is injurious to the early phases of the infection process with certain viruses'. His treatments differ so widely from ours that there may be no common phenomenon. As leaf cells contain so much water, however, it seems unlikely that water would directly inhibit infection. Of the possible indirect actions, decreasing the supply of oxygen seems the most obvious, particularly as exposing recently inoculated leaves to atmospheres containing $50 \% \mathbf{C O}_{2}$ also decreases numbers of local lesions (Kalmus \& Kassanis, 1944). We have no positive evidence that some oxidation process is concerned, and bubbling air through water in which inoculated leaves were submerged did not affect the numbers of local lesions produced. Whatever the mechanism, it operates against some process that occurs only in the early phases of infection, for submersion does not decrease the rate at which virus is produced in infected leaves. On the contrary, leaves submerged a day after inoculation yield extracts containing more TMV or RTNV than do comparable leaves that are left on plants. Also, the local lesions that develop on submerged leaves, particularly those produced by RTNV in $N$. glutinosa, are often larger than those on leaves left on plants (Pl. 1, fig. 1).

\section{Thiouracil and virus production}

Table 2 shows how the yield of TMV obtained from inoculated leaves is increased when they are detached from the plant and floated. The differential treatments were started $24 \mathrm{hr}$. after the leaves were inoculated, and the leaves were macerated and the virus isolated from the extracts 9 days after starting the treatments. Leaves floated in water gave nearly twice as much virus as leaves left on the plants, and floating in a solution of sucrose and $\mathrm{Ca}\left(\mathrm{H}_{2} \mathrm{PO}_{4}\right)_{2}$ produced nearly three times as much. Spraying leaves on the plants daily with thiouracil decreased the yield of virus, but less so than did floating in water containing thiouracil and much less so than floating in the nutrient solution containing thiouracil.

Derivatives of thiouracil seem not to interfere with the multiplication of 
TMV, and floating tobacco leaves in nutrient solutions containing $100 \mathrm{mg} . / \mathrm{l}$. of either methyl-thiouracil or thiouracil-5-acetic acid gave as much virus as did floating leaves in nutrient solutions alone.

Table 2 also shows that uracil can completely counteract thiouracil's usual ability to inhibit virus production. This action seems specific to uracil; when adenine, cytosine or guanine were added to solutions of thiouracil, the amount of TMV produced was not significantly greater than that in leaves floated in solutions containing only thiouracil. Mercer, Lindhorst \& Commoner (1953) also found this to be so, and they showed further that only uracil counteracts the ability of thiocytosine, thiothymine and two purine analogues, to inhibit the accumulation of TMV.

\section{Table 2. Concentration of tobacco mosaic virus in sap from inoculated tobacco leaves treated in different reays}

$\begin{array}{lc} & \begin{array}{c}\text { Virus } \\ \text { concentration } \\ \text { (g./l. of sap) }\end{array} \\ \text { Treatment of leaves } & 0 \cdot 36 \\ \text { water on plants } & 0 \cdot 14 \\ 100 \mathrm{mg} \text {. thiouracil/l. } & 0 \cdot 55 \\ \mathrm{mg} \text {. thiouracil/l. } & 0 \cdot 10 \\ \mathrm{mg} \text {. thiouracil/l. and } 100 \mathrm{mg} \text {./l. uracil } & 0 \cdot 50 \\ \text { rient solution } & 1 \cdot 01 \\ \text { trient solution and } 100 \mathrm{mg} \text {. thiouracil/l. } & 0 \cdot 05 \\ \text { trient solution and } 100 \mathrm{mg} \text {. thiouracil } & 1 \cdot 10\end{array}$

Inoculum was purified virus at $1 \mathrm{~g} . / \mathrm{l}$. Nutrient solution contained $10 \mathrm{~g}$./l. sucrose and $0 \cdot 2$ g./l. $\mathrm{Ca}\left(\mathrm{H}_{2} \mathrm{PO}_{4}\right)_{2} \mathrm{H}_{2} \mathrm{O}$.

Commoner \& Mercer (1952) found no qualitative differences between TMV formed in leaves floated in solutions with and without thiouracil. When we have purified TMV from treated and untreated leaves, we also have noticed no differences in general physical, chemical and serological behaviour, and, weight for weight, virus from treated leaves was as infective as that from untreated ones. When we assayed extracts from treated and untreated leaves both serologically and by infectivity tests, the two methods always gave comparable results. It seems, therefore, that thiouracil does not alter significantly the proportions in which infective and non-infective particles normally occur, but we have not attempted to fractionate the extracts by differential centrifugation and so have no critical experiments that would detect minor changes (Bawden \& Pirie, 1945).

We have found that thiouracil inhibits TMV production most when conditions are such that without it most virus would be produced. Not only is the proportional decrease in virus greatest in such conditions, but less total virus is formed in the presence of thiouracil when conditions favour virus production than when they are less favourable. Of the conditions we have used, maximum virus is produced when inoculated leaves are floated in solutions of sucrose and $\mathrm{Ca}\left(\mathrm{H}_{2} \mathrm{PO}_{4}\right)_{2}$ and exposed to daylight. Table 3 shows 
that in these conditions thiouracil inhibited the production of TMV almost completely, whereas it was almost ineffective with leaves floated in water and kept in darkness. We do not know whether this is because such leaves contain more uracil. In experiments we have made at different times with leaves floated in water, the amount of virus obtained in extracts has varied widely. The variations presumably reflect different physiological states of the leaves at the time they were floated, perhaps their sugar and phosphorus contents. Whatever the cause of the variations, the ability of thiouracil to inhibit TMV formation usually also varied and was small when the control leaves produced little virus.

\section{Table 3. The varying ability of thiouracil to inhibit the multiplication of tobacco mosaic virus in leaves treated differently}

\begin{tabular}{llclrr} 
& \multicolumn{2}{c}{ Leaves in water } & \multicolumn{2}{l}{ Leaves in nutrient solution } \\
A. Leaves in daylight & Water only & $64^{*}$ & & Nutrient only & 192 \\
& Thiouracil $100 \mathrm{mg} . / 1$. & 8 & & Thiouracil $100 \mathrm{mg} . / 1$. & 1 \\
B. Leaves in darkness & Water only & 48 & Nutrient only & 128 \\
& Thiouracil $100 \mathrm{mg} / \mathrm{l}$. & 32 & & Thiouracil $100 \mathrm{mg} . / 1$. & 2
\end{tabular}

* Relative virus contents expressed as the reciprocal of the precipitation end-points when titrated against TMV antiserum. Leaves macerated 6 days after floating.

Table 4 shows that thiouracil can slow the multiplication rate of TMV at any time between infection and maximum virus content, although its inhibiting effect is less when virus has already multiplied considerably than it is when the treated leaves contain little virus. The leaves were detached at various times after inoculation, and floated in nutrient solutions, with and without thiouracil at $100 \mathrm{mg}$./l., for 7 days before they were macerated and their virus contents estimated. To find how much virus was produced before the differential treatments were started, some leaves were macerated at the times the others were floated. The leaves floated 12 days after inoculation were young leaves that had become infected by systemic spread of the virus, and thiouracil also decreased the rate at which TMV was produced in these.

When leaves are floated in solutions of thiouracil within a day or two after inoculation, they usually show no external symptoms, though sometimes they become rather more chlorotic than do comparable leaves floated in water or nutrient solutions. By contrast, when the interval between inoculation and floating is longer and the virus has already multiplied detectably before the leaves are exposed to thiouracil, they develop necrotic lesions, the size and distribution of which depend on the virus content of the leaves. Table 4 indicates this phenomenon, which is described in more detail later.

Exposing infected leaves to thiouracil does not inactivate virus already formed, nor does it have any permanent effect on the ability of the cells to maintain virus multiplication. The speed with which leaves floated in solutions of $100 \mathrm{mg}$. thiouracil/l. regained ability to produce TMV when they were washed in running water and then floated in water or nutrient solutions, 
varied considerably from experiment to experiment. Sometimes the washed leaves started to produce virus in the first day, whereas at others they took 2 or 3 days before the rate of virus multiplication was comparable with that in untreated leaves. We have not studied the reasons for this variation, but they may be correlated with the physiological condition of the leaves, which, as we have already shown, affects the extent to which thiouracil inhibits virus formation.

Table 4. The effect of thiouracil applied at different times after tobacco leaves were infected with tobacco mosaic virus

\begin{tabular}{|c|c|c|c|}
\hline $\begin{array}{l}\text { Days between } \\
\text { inoculation } \\
\text { and start of } \\
\text { treatment }\end{array}$ & Treatment* & $\begin{array}{c}\text { Relative virus } \\
\text { content } \\
\text { (Reciprocals of } \\
\text { precipitation } \\
\text { end-points) }\end{array}$ & Necrotic lesions \\
\hline 1 & $\begin{array}{l}\text { Thiouracil } \\
\text { Nutrient solution }\end{array}$ & $\begin{array}{r}1 \\
128\end{array}$ & - \\
\hline 3 & $\begin{array}{l}\text { Sample before treatment } \\
\text { Thiouracil } \\
\text { Nutrient solution }\end{array}$ & $\begin{array}{r}8 \\
8 \\
256\end{array}$ & Small rings \\
\hline 6 & $\begin{array}{l}\text { Sample before treatment } \\
\text { Thiouracil } \\
\text { Nutrient solution }\end{array}$ & $\begin{array}{r}16 \\
48 \\
512\end{array}$ & Rings \\
\hline 9 & $\begin{array}{l}\text { Sample before treatment } \\
\text { Thiouracil }\end{array}$ & $\begin{array}{l}128 \\
256\end{array}$ & $\begin{array}{l}\text { Large rings and lines along } \\
\text { the veins }\end{array}$ \\
\hline & Nutrient solution & 512 & - \\
\hline 12 & $\begin{array}{l}\text { Sample before treatment } \\
\text { Thiouracil } \\
\text { Nutrient solution }\end{array}$ & $\begin{array}{l}128 \\
128 \\
512\end{array}$ & Patterns along basal veins \\
\hline
\end{tabular}

* Detached leaves were floated in solutions of $10 \mathrm{~g}$. sucrose/l. and $0 \cdot 2 \mathrm{~g} \cdot \mathrm{Ca}\left(\mathrm{H}_{2} \mathrm{PO}_{4}\right)_{2} \mathrm{H}_{2} \mathrm{O} / \mathrm{l}$. with and without $100 \mathrm{mg}$. thiouracil/l., and were left for 7 days before being macerated. Some of the leaves detached at 3, 6,9 and 12 days were macerated to find their virus contents when the treatments were started. The leaves floated after 12 days were uninoculated young leaves, becoming systemically invaded.

Thiouracil does not act specifically against TMV. On the contrary, it inhibits the multiplication in tobacco leaves of all the viruses we have tested. Results with three are shown in Table 5: tobacco leaves were detached and floated the day after they were inoculated, and they were macerated 1 week later, when the virus contents of the extracts were assayed serologically. The multiplication of potato virus $X$ is also inhibited when inoculated leaves on the plant are sprayed daily with $100 \mathrm{mg}$./l. solutions of thiouracil. As with TMV, spraying has less effect than floating in solutions of thiouracil; in experiments when tobacco leaves floated in nutrient solutions, or left on the plant and sprayed with water, gave extracts with precipitation end-points of $1 / 128$ to $1 / 256$, extracts from leaves sprayed with thiouracil gave end-points of $1 / 8$ or $1 / 16$, whereas those from leaves floated in thiouracil failed to precipitate or did so only when undiluted. Experiments in which RTNV and tomato aucuba mosaic virus were inoculated to opposite halves of the same 
tobacco leaves, which were floated a day later, have sometimes suggested that thiouracil decreases the numbers of local lesions formed by tomato aucuba mosaic virus more than those formed by RTNV. However, as Table 6 shows, the multiplication of RTNV in tobacco leaves is also greatly inhibited. Tobacco leaves floated in nutrient solution a day after they were inoculated with RTNV gave extracts 6 days later that were 25 times as infective as extracts from comparable leaves floated in $100 \mathrm{mg}$./l. solution of thiouracil.

Table 5. Thiouracil and the multiplication of four viruses in detached leaves

\begin{tabular}{|c|c|c|c|}
\hline \multirow[b]{2}{*}{ Virus } & & \multicolumn{2}{|c|}{ Reciprocals of serological titr } \\
\hline & Host & $\begin{array}{l}\text { Leaves in } \\
\text { thiouracil } \\
100 \mathrm{mg} . / \mathrm{l} .\end{array}$ & $\begin{array}{c}\text { Leaves in } \\
\text { water }\end{array}$ \\
\hline Potato virus $X$ & Tobacco & o & 160 \\
\hline Potato virus $Y$ & Tobacco & $\mathbf{0}$ & 8 \\
\hline Henbane mosaic & Tobacco & $\mathbf{0}$ & 16 \\
\hline Broad bean mottle & Broad bean & 32 & 32 \\
\hline
\end{tabular}

Table 6. Thiouracil and the multiplication of a tobacco necrosis virus in tobacco and French bean

\begin{tabular}{llcccc}
\multirow{2}{*}{$\begin{array}{l}\text { Host plant } \\
\text { Bean }\end{array}$} & & \multicolumn{4}{c}{ No. of lesions* with sap diluted } \\
& Thiouracil & 32 & 60 & 138 & - \\
Tobacco & Control & 19 & 78 & 118 & - \\
& Thiouracil & - & 20 & 112 & 206 \\
& Control & 102 & 195 & 555 & - \\
& * Total number of lesions on six French-bean leaves.
\end{tabular}

The ability of thiouracil to prevent virus formation does not extend to all hosts. Table 6 shows that RTNV multiplies equally in French-bean leaves floated in nutrient solutions with thiouracil as in solutions without it. Similarly, Table 5 shows that thiouracil has no effect on the multiplication of broad bean mottle virus in broad bean. This is so despite the fact that the inoculated leaves, which normally show no symptoms, develop large chocolatecoloured lesions after 4 days in the thiouracil solutions. Uninfected leaves in thiouracil solutions develop no such lesions.

\section{Inhibition of infection and effects on host plants}

Many substances, of widely different chemical constitutions, can affect the ability of plant viruses to cause infections. Characteristically, such inhibitors have no permanent effect on the viruses when incubated with them in vitro, and infectivity is fully affected immediately the inhibitors are added to inocula. How they act is unknown, but the extent to which some of the most powerful inhibitors decrease infectivity depends on the species of plant inoculated, whereas it is largely independent of the kind of virus. Thus, it seems likely that they affect some host-cell components with which the viruses need to interact during the initiation of infection. 
Table 7 shows that thiouracil can be added to the list of substances that decrease the infectivity of virus preparations, and that it does so both in tobacco and French bean. To prevent the occurrence of infection, the concentration of thiouracil in inocula needs to be greater than that needed to decrease the rate of virus multiplication in floated tobacco leaves infected with TMV. As with trichothecin (Bawden \& Freeman, 1952), spraying leaves with thiouracil before or after they are inoculated with viruses decreases the numbers of local lesions. Spraying inhibits infection more in tobacco than in French bean (Table 8), and in both species fewest lesions occur when the leaves are sprayed near to the time of inoculation. In tobacco, possibly because in this host thiouracil also has the additional ability to interfere with virus multiplication in infected leaves, spraying as long as 2 days after inoculation with tomato aucuba mosaic virus still decreases the number of lesions produced.

\section{Table 7. Thiouracil as an inhibitor of infectivity}

$\begin{array}{cccc}\begin{array}{c}\text { Concentration } \\ \text { of thiouracil } \\ \text { in inoculum } \\ \text { (mg./1.) }\end{array} & \begin{array}{c}\text { Tobacco } \\ \text { mosaic virus }\end{array} & \begin{array}{c}\text { Tobacco } \\ \text { in } N \text {. glutinosa }\end{array} & \begin{array}{c}\text { Tomato aucuba } \\ \text { in French bean } \\ \text { mosaic virus } \\ \text { in tobacco }\end{array} \\ \begin{array}{c}\text { i500 } \\ 625\end{array} & 0 * & 0 & 2 \\ 156 & 10 & 11 & 9 \\ 39 & 137 & 199 & 48 \\ 0 & 210 & 219 & 106 \\ & 189 & 487 & 132 \\ & \text { Total number of lesions from nine leaves. }\end{array}$

Table 8. Inhibition of infection by spraying with thiouracil

$\begin{array}{ccc}\begin{array}{c}\text { Interval between } \\ \text { spraying and } \\ \text { inoculation }\end{array} & \begin{array}{c}\text { Tomato } \\ \text { aucuba mosaic } \\ \text { virus in tobacco }\end{array} & \begin{array}{c}\text { Tobacco } \\ \text { necrosis virus }\end{array} \\ \begin{array}{c}\text { French bean } \\ 48 \mathrm{hr} \text {. before }\end{array} & 3^{*} & 12 \dagger \\ 24 \mathrm{hr} \text {. before } & 2 & 12 \\ 1 \mathrm{hr} \text {. before } & 0 \cdot 3 & 8 \\ 24 \mathrm{hr} \text {. after } & 3 & 19 \\ \mathbf{4 8} \mathrm{hr} \text {. after } & 10 & 26 \\ \text { Unsprayed control } & 27 & 29 \\ & & \end{array}$

The experiments in which leaves left on plants were exposed to thiouracil, either contained in the inoculum or sprayed as separate solutions, showed effects of thiouracil that are not apparent when mature leaves are floated in solutions. With French bean, for example, the first-formed leaves were used for local-lesion counts and for experiments on the multiplication of RTNV. When floated in $100 \mathrm{mg}$./1. solutions of thiouracil, such leaves show few or no effects. Nor are they much affected when rubbed or sprayed with the concentrated solutions of thiouracil used to inhibit infection. The young trifoliate leaves of these plants, however, even though they are not directly treated with thiouracil, become almost completely yellow, an effect that persists for some 
days, when they regain their normal green. Spraying uninfected broad-bean plants with thiouracil produces little response, but it affects plants inoculated with broad-bean mottle virus. The inoculated leaves develop chocolate-coloured local lesions (Pl. 1, fig. 2), similar to those on infected leaves floated in solutions of thiouracil, and instead of the mottle that normally develops on young leaves when systemically invaded, these and the stem apex become black and die.

Matthews (1953a) found that spraying tobacco plants with thiouracil turns the young leaves yellow, makes their edges curl, and checks apical growth. We have confirmed this observation. When sprayed daily with $100 \mathrm{mg}$. thiouracil/l., the young leaves develop chlorotic areas on the fourth day and start to curl. Sprayed with $1 \mathrm{~g}$./1. solutions, the young leaves are completely bleached after 4-6 days. While spraying is continued, the plants make little or no growth, but when it stops they gradually recover and after a week or more show few effects. When tobacco plants, recently inoculated with TMV on their lower leaves, are sprayed daily with thiouracil solutions, the young leaves become chlorotic as in uninfected plants, but the inoculated leaves behave differently (Pl. 1, fig. 3). They develop necrotic spots or rings, the number of which depends on the virus content of the inoculum and the size on the time that has elapsed between inoculation and spraying (Pl. 1, fig. 4). Spraying a day after inoculation causes small necroses to appear within 3 or 4 days. As the delay between inoculation and spraying is progressively increased, so the spots and rings become increasingly larger. This fits with what is known of the manner in which viruses spread from the initial infection sites, and it suggests that the necrosis is a reaction to thiouracil of cells in which virus is actively multiplying. The customary method whereby the local lesions of TMV in tobacco are made visible is to detach the leaves, decolorize them with ethanol and stain with iodine (Holmes, 1931). Spraying with thiouracil solutions is a simpler technique and has the added advantage that the leaves are not detached and killed, but we have not tested its usefulness for local-lesion counts. The interaction between thiouracil and infected cells that leads to necrosis is not restricted to inoculated leaves. When young leaves are floated in or sprayed with thiouracil at the time they are becoming systemically invaded and would normally become yellow around the veins, the yellowing in parts of the leaves is replaced by necrosis. Young leaves with the mosaic symptoms typical of a full systemic infection may develop a few isolated necrotic areas, but their main reaction is to become yellow so that the mosaic disappears. It seems that the necrotic rings and patterns are mainly a response of recently infected cells in which the virus is multiplying rapidly. A simple explanation would be that infected cells contain no free uracil, but spraying plants with mixtures of uracil and thiouracil does not prevent the necrosis. Nor does spraying with such mixtures prevent thiouracil from producing its usual chlorosis on young leaves of tobacco and Frenchbean plants.

Matthews (1953a) found that spraying guanazolo on $N$. glutinosa leaves inoculated with lucerne mosaic virus considerably delayed the time taken 
for plants to become systemically infected, and he used the delay to measure the extent to which the substance inhibited virus multiplication. Spraying thiouracil over tobacco leaves recently inoculated with TMV also delays the onset of systemic infection, the length of the delay depending on the interval between inoculation and spraying and on the strength of the solutions sprayed. Spraying with concentrated solutions immediately after inoculation may prevent systemic infection, but spraying immediately with $100 \mathrm{mg}$. thiouracil/., or spraying with concentrated solutions a day or more after inoculation, does not prevent the young leaves from ultimately becoming infected. The concentrated solutions applied immediately after inoculation presumably prevent infection from being initiated (Table 7), whereas after the virus has started to multiply, although thiouracil slows the rate of multiplication, it does not stop it completely or inactivate the virus already formed. Delay in the development of systemic symptoms is not a convenient method of studying the inhibiting action of thiouracil, for the young leaves on sprayed plants become so chlorotic, and the new growth is so abnormal, that the initial symptoms are difficult to detect. When spraying is stopped, apical growth is resumed and infected plants gradually develop the usual symptoms. Sap from leaves of such plants contains as much virus as sap from comparable leaves of unsprayed plants.

\section{DISCUSSION}

In discussing the ability of thiouracil to inhibit the rate of TMV formation, Commoner \& Mercer (1952) say 'the simplest, but by no means the most likely explanation of this effect, is that thiouracil prevents the entry of uracil into TMV nucleic acid and thereby forestalls the formation of the virus particle. Alternatively, it is possible that thiouracil blocks the participation of uracil in some process more remotely related to the TMV particle.' Our results do not decide definitely between these two; nor, indeed, are they the only possibilities. For example, Matthews (1953 $b$ ) found that guanazolo, which also inhibits virus formation in Nicotiana sp., although less thoroughly than does thiouracil (Mercer et al. 1953), is incorporated in the nucleic acid of TMV formed in treated tobacco leaves, and he suggests that virus formation may be inhibited because such particles are 'sterile'. Similarly, Jeener \& Rosseels (1953) state, in a preliminary note, that thiouracil can be incorporated in the nucleic acid of TMV, and they also suggest that this modification may hinder multiplication.

The inhibitory action of thiouracil on virus formation cannot yet be interpreted with any certainty, and discussion is worth while only in as far as it indicates further lines of work. An obvious one is to find whether virus particles containing thiouracil or guanazolo do differ biologically from normal particles. The fact that anomalous substances can be incorporated in virus particles has great intrinsic interest, but virus particles are unlikely to be the only components of cells to which such things happen, and its relevance to the problem of virus multiplication will remain uncertain until the chemically modified particles are shown to multiply more slowly or to interfere with the 
multiplication of normal particles. Also uncertain is the relevance of what happens when thiouracil is having relatively little effect on virus multiplication, the conditions under which it has been found to be incorporated in TMV, to what happens when it is inhibiting so strongly that very little virus is formed. The small amount of TMV extractable from tobacco leaves that are floated a day after inoculation in nutrient solution containing thiouracil, is certainly not all non-infective, and our tests did not suggest that its ability to initiate new infections in $N$. glutinosa differed greatly from that of normal virus. However, although infectious towards $N$. glutinosa, the particles might not be able to multiply in tobacco cells containing thiouracil. Alternatively, the infective particles could be normal ones, produced in parts of cells incompletely invaded by thiouracil, and if these were more readily extractable than those modified by thiouracil, then the modified and possibly non-infective particles would be selectively retained in the leaf residues.

Another line of work that might profitably be pursued is the comparative study of tobacco and French-bean leaves, to try and find reasons for the ability of thiouracil to inhibit virus formation in one but not the other. Is RTNV containing thiouracil able to multiply in French bean but not in tobacco? Or is thiouracil not incorporated in viruses when they are being formed in French bean? Or is the prime effect of thiouracil on some host component?

The results of spraying plants with thiouracil show that it does disturb their metabolism, producing particularly obvious effects in young tissues where continued protein synthesis is needed, and it is reasonable to assume that effects on virus formation may be correlated with this disturbance. Failure of some host-cell mechanism is reasonably suspected, too, from the fact that what specificity there is in the ability of thiouracil to inhibit virus formation seems to be determined by the identity of the host plant and not by the virus. Thus, although in tobacco thiouracil seems to act indiscriminately and inhibit the formation of any virus including RTNV, it does not affect the multiplication of RTNV in French bean. Effects on the external appearance and on the growth of host plants, however, need not be directly related to effects on virus production. Indeed, there are indications that the two are separate. Uracil, which neutralizes thiouracil's ability to inhibit virus multiplication in tobacco, does not neutralize its effects on young leaves and on apical growth. Also, when French-bean plants are sprayed with thiouracil, the young leaves react in a manner superficially similar to tobacco leaves, showing that host-plant metabolism can be affected without affecting the ability to support virus multiplication. One explanation of these differences could be that some system concerned with protein synthesis in tobacco, but not in bean, is adversely affected by thiouracil. A nucleic acid is the obvious suspect, but there is little call to speculate on the nature of a substance whose existence is unestablished. Another and simpler explanation would be that French-bean leaves contain more uracil than do tobacco leaves and so are better able to neutralize the power of thiouracil to inhibit virus formation. We have not attempted to assess the relative uracil contents of the different plants, but preliminary paper chromatograms suggest that this would not be 
difficult. Our qualitative tests were made with sap from tobacco leaves only, and they show that the synthesis of TMV in this host does affect the contents of uracil and of other purines and pyrimidines. Uracil was easily detected in sap from healthy tobacco leaves after it was freed from protein and nucleic acid. It was also detected in sap from leaves that had been inoculated with TMV and treated with thiouracil so that virus multiplication was largely inhibited, whereas it was not detected in sap from untreated leaves in which the virus had multiplied extensively. Thus the multiplying virus normally seems to sequestrate the free uracil, but the inability of virus to multiply in the presence of thiouracil seems not to be attributable to a loss of uracil. How extra uracil counteracts the inhibiting power of thiouracil is unexplained, but. it may prevent the incorporation of thiouracil in either the virus or some host nucleic acid, or both.

We are indebted to Dr P. P. Hopf, of Ward, Blenkinsop and Company, Ltd., for gifts of uracil, thiouracil and its derivatives; also to Dr A. Kleczkowski who made the chromatograms.

\section{REFERENCES}

Bawden, F. C. \& Freeman, G. G. (1952). The nature and behaviour of inhibitors of plant viruses produced by Trichothecium roseum Link. J. gen. Microbiol. 7, 154.

Bawden, F. C. \& Pirie, N. W. (1945). The separation and properties of tobacco mosaic virus in different states of aggregation. Brit. J. exp. Path. 26, 294.

Commoner, B. \& Mercer, F. (1951). Inhibition of the biosynthesis of tobacco mosaic virus by thiouracil. Nature, Lond. 168, 113.

Commoner, B. \& Mercer, F. (1952). The effect of thiouracil on the rate of tobacco mosaic virus biosynthesis. Arch. Biochem. Biophys. 35, 278.

Holmes, F. O. (1931). Local lesions of mosaic in Nicotiana tabacum L. Contr. Boyce Thompson Inst. 3, 163.

Jeener, R. \& Rosseels, J. (1953). Incorporation of 2-Thiouracil-85S in the ribose nucleic acid of tobacco mosaic virus. Biochim. Biophys. Acta, 11, 438.

Kalmus, H. \& Kassanis, B. (1944). Reduction by carbon dioxide of susceptibility of beans to tobacco necrosis viruses. Nature, Lond. 154, 641.

Kalmus, H. \& Kassanis, B. (1945). The use of abrasives in the transmission of plant viruses. Ann. appl. Biol. 32, 230.

Kassanis, B. (1953). Some effects of sucrose and phosphorus in increasing the multiplication of tobacco mosaic virus in detached tobacco leaves. J. gen. Microbiol. (in the Press).

Matthews, R. E. F. (1953a). Chemotherapy and plant viruses. J. gen. Microbiol. 8, 277.

Matthews, R. E. F. (1953b). Incorporation of 8-Azaguanine into nucleic acid of tobacco mosaic virus. Nature, Lond. 171, 1065.

Mercer, F. L., Lindhorst, T. E. \& Commoner, B. (1953). Inhibition of tobacco mosaic virus biosynthesis by 2 -thiopyrimidines. Science, 117,558 .

Yarwood, C. E. (1952). Deleterious action of water in plant virus inoculations. Nature, Lond. 169, 502. 
Journal of General Microbiology, Vol. 10, No. 1
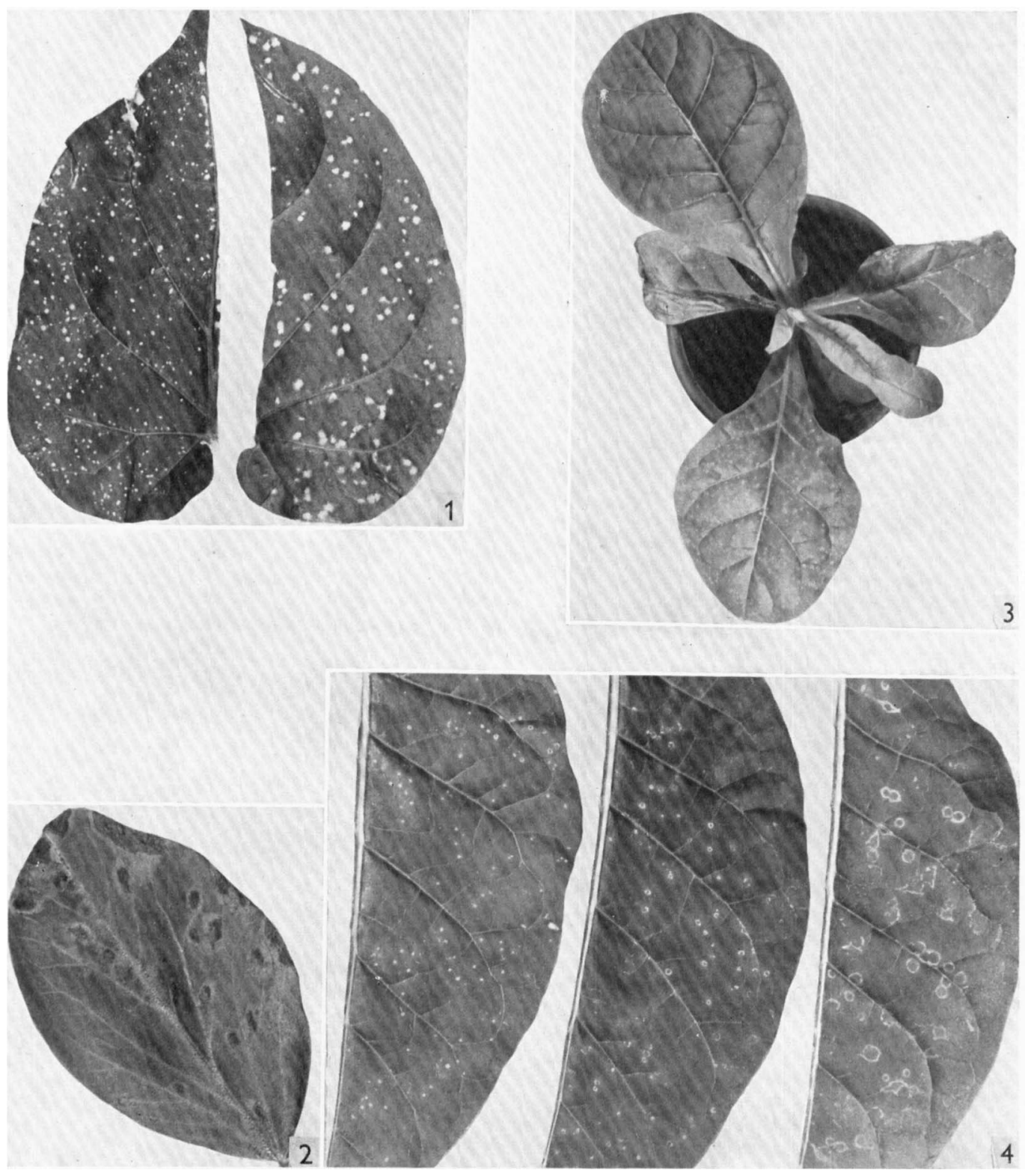

F. C. Bawden \& B. Kassanis-'Thiouracil and plant viruseis. Plate 1 


\section{EXPLANATION OF PLATE}

Fig. 1. Half leaves of Nicotiana glutinosa inoculated with Rothamsted tobacco necrosis virus, showing (left) the small lesions normally produced, and (right) large lesions when leaf is floated in water.

Fig. 2. Leaflet of Vicia faba inoculated with broad bean mottle virus showing the necrotic lesions developed by spraying with thiouracil.

Fig. 3. Tobacco plant inoculated with tobacco mosaic virus and sprayed with thiouracil. The inoculated leaves have many necrotic lesions and the young leaves are chlorotic and curled.

Fig. 4. Half leaves from tobacco plants sprayed with thiouracil at different times after inoculation with tobacco mosaic virus. Note the increase in size of necrotic lesions with increasing time between inoculation and spraying. Left-hand half-leaf sprayed 1 day after inoculation; centre 2 days and right-hand 3 days.

(Received 13 August 1953) 